\title{
Diversity and distribution of microalgae in coastal areas of East Java, Indonesia
}

\author{
UMI ZAKIYAH ${ }^{1 \bullet}$, MULYANTO ${ }^{1}$, LUCIA TRI SUWANTI ${ }^{2}$, MOCHAMAD DONNY KOERNIAWAN ${ }^{3}$, \\ EKO AGUS SUYONO ${ }^{4}$, ARIEF BUDIMAN ${ }^{5}$, ULFAH JUNIARTI SIREGAR ${ }^{6, v}$ \\ ${ }^{1}$ Department of Aquatic Resources Management, Faculty of Fisheries and Marine Science, Universitas Brawijaya. J1. Veteran Malang 65145, East Java, \\ Indonesia. Tel/fax.: +62-341-553512, Fax.: +62-341-556837, `email: umi.zakiyah@gmail.com \\ ${ }^{2}$ Department of Veterinary Parasitology, Faculty of Veterinary Medicine, Universitas Airlangga. Jl. Mulyorejo, Kampus C Unair, Surabaya 60115, East \\ Java, Indonesia \\ ${ }^{3}$ Department of Architecture, School of Architecture, Planning, and Policy Development, Institut Teknologi Bandung. Jl. Ganesha No. 10, Bandung \\ 40132, West Java, Indonesia \\ ${ }^{4}$ Faculty of Biology, Universitas Gadjah Mada, Jl. Teknika Selatan, Sleman 55281, Yogyakarta, Indonesia \\ ${ }^{5}$ Department of Chemical Engineering, Faculty of Engineering, Universitas Gadjah Mada, Jl. Grafika 2, Sleman 55281, Yogyakarta, Indonesia \\ ${ }^{6}$ Department of Silviculture, Faculty of Forestry, Institut Pertanian Bogor. J1. Lingkar Akademik, Dramaga, Bogor 16680, West Java, Indonesia \\ Tel.:+62-251-8626806, Fax.: +62-251-8621256, ^^email: ulfahjs@apps.ipb.ac.id
}

Manuscript received: 29 November 2019. Revision accepted: 21 February 2020.

\begin{abstract}
Zakiyah U, Mulyanto, Suwanti LT, Koerniawan MD, Suyono EA, Budiman A, Siregar UJ. 2020. Diversity and distribution of microalgae in coastal areas of East Java, Indonesia. Biodiversitas 21: 1149-1159. Indonesia is well known as one of hotspot for biodiversity, including marine resources. However, Indonesia biodiversity has declined rapidly due to the changes in the aquatic environmental quality as the consequence of human activities. Biodiversity loss has been well studied in larger organisms, however, less is known for microorganisms, such as microalgae. Microalgae have received much attention recently due to its potential as renewable energy sources. This study aimed at describing biodiversity and distribution of microalgae in coastal areas of East Java and Madura, Indonesia. Six sites, i.e. Trenggalek and Sendangbiru representing south coast, Banyuwangi and Situbondo representing north coast of East Java, Pasongsongan and Pamekasan representing Madura north and south coast, respectively were sampled, which representing different background of anthropogenic development in these areas. Results showed that seawater condition in all sites is still good, with average $\mathrm{pH} 8.0$ despite intense human activities, such as ecotourism, fishing and boat harbor, as well as residential area that has the potential to produce a lot of waste. Totally, there were 35 genera from all locations with varying abundance in each location and diversity index ranging from 1.105-3.312. Although most genera belonged to Bacyllariophyta, domination indices showed that there was not any single specific domination in all locations. Morisita indices showed that most distribution gave positive values indicating clumped dispersion of microalgae in all locations. Higher Shannon-Weaver indices characterized the south coast of East Java and Madura compared to the north coast of East Java area, which corresponded with lower dominancy indices.
\end{abstract}

Keywords: Biodiversity, East Java, Madura, microalgae

\section{INTRODUCTION}

Indonesia has about $2 / 3$ of its territory as sea and is well known as one of mega-diversity spots in the world. However rapid increasing population and unsustainable utilization of its natural resources have resulted in rapid decline of its biodiversity. Biodiversity loss has been well studied in larger organisms, in terrestrial areas, however little is known for microorganisms, even less in marine areas, such as microalgae (Suyono et al. 2016). Microalgae have recently received much attention due to its role as primary producers and its high potential source of renewable energy (Chisti 2007; Prartono et al. 2010).

Many publications have reported efforts to masscultivate microalgae with various manipulation to produce bio-oil for renewable energy and other side products. Microalgae is a unicellular organism, which exists as a single cell or a group of cells in both freshwater and marine ecosystem. Their biodiversity is enormous, while only a fraction has been characterized. Since these organisms produce biomass and provide energy for all organisms above them, their potential to produce bioenergy is very high per cubic space (Singh and Gu 2010). Microalgae potential application also includes production of food supplements and cosmetics, especially astaxanthin (PoncePalafox et al. 2006). Therefore it is necessary to explore further their capability to produce biomass and other compounds in the culture of microalgae. In autotrophic microalgae cultivation supply of carbon dioxide must be continuous. However, to achieve a significant result, the most crucial issue using microalgae in biofuels production is mainly the high cost regarding the mass-culture for biomass growth (Riberio and Pereira da Silva 2013). In order to get more economically feasible production a more efficient technological innovation is needed.

Microalgae as source of third generation of biofuel could potentially bypass any problems found in the previous generation of biofuels using technology available today (Alaswad et al. 2015). Among microalgae species considered to be alternative energy sources for biofuels are Chlorella sp, Scenedesmus sp. Dunaliella sp, Spirulina sp, and Botryococcus braunii (Amini and Susilowati 2010). 
Microalgae are easily cultivated, requiring only basic nutrients and enough light to conduct photosynthesis and produce various products in large amounts over short periods of time (Ali et al. 2014). Microalgae lipids can be processed into biofuels, while other valuable co-products are valuable sources for food and antioxidants. The availability of microalgae species that can be cultured to meet the need for biofuel production from a mass culture becomes crucial (Dong et al. 2016) However, exploration of the available species from both fresh and marine environments should be conducted previously. The on going research on the newly found species regarding their composition that has close relation with biofuels production should become the next issues to be executed and finally, the selected species can be generated to produce valuable bio and coproducts in massive culture. This study aimed to describe biodiversity and distribution of microalgae in coastal areas of East Java and Madura, Indonesia.

\section{MATERIALS AND METHODS}

\section{Sampling locations}

The locations of this research were six different coastal areas of East Jawa Province, Indonesia (Figure 1) including Sumenep (SUM) and Pamekasan (PAM), Situbondo (ST), Banyuwangi (BW), Sendang Biru (SD), and Trenggalek (TG) (Figure. 1 to 7 ). In every regency, the samples were taken from coastal areas in two site stations i.e. station 1 (PL 1) and station 2 (PL 2). These areas were chosen due to their differences in landuse of the surrounding areas, which were, fish landing harbor (Malang and Situbondo) that presumably can make a pollution from fisherman's ship fuel residue, Ecotourism areas that created many trash from the tourists such as plastics wastes (Trenggalek and Banyuwangi) and boat harbor as well as municipalities that created a mixed pollution such a fuel residue and household waste at the same time (Sumenep and Pamekasan). These different backgrounds were assumed to have high impact on the water quality observed in all the parameters, i.e. temperature, salinity, $\mathrm{pH}$, nitrate, phosphate, and silicate content as well, that affect the microalgae biodiversity in the seawater. This research was conducted in April and May 2019 by collecting seawater from each station of each location, followed by sieving microalgae in situ. The water quality parameters i.e. temperature, salinity, and $\mathrm{pH}$ were also recorded in situ.

\section{Water quality analysis}

Water samples were taken using polyethylene $1 \mathrm{~L}$ bottle samples. Water quality parameters such as $\mathrm{pH}$ were measured using $\mathrm{pH}$-meter, salinity using refractometer while temperatures using mercury-based thermometer. The $1000 \mathrm{~mL}$ of water samples were kept in a cool condition (about $4^{\circ} \mathrm{C}$ ) and transported to the Laboratorium Hydrobiology in Faculty of Fisheries and Marine Sciences, Faculty of Fisheries and Marine Science, Brawijaya University, Malang. for analysis. Parameters such as phosphate and nitrate were analyzed using colorimetric specification with UV-Vis Spectrometry methods (Bengen 2000). Silicate was analyzed using spectrophotometry (APHA 2005), while other parameters such as temperature, salinity, pH (APHA 2005) were measured in situ.

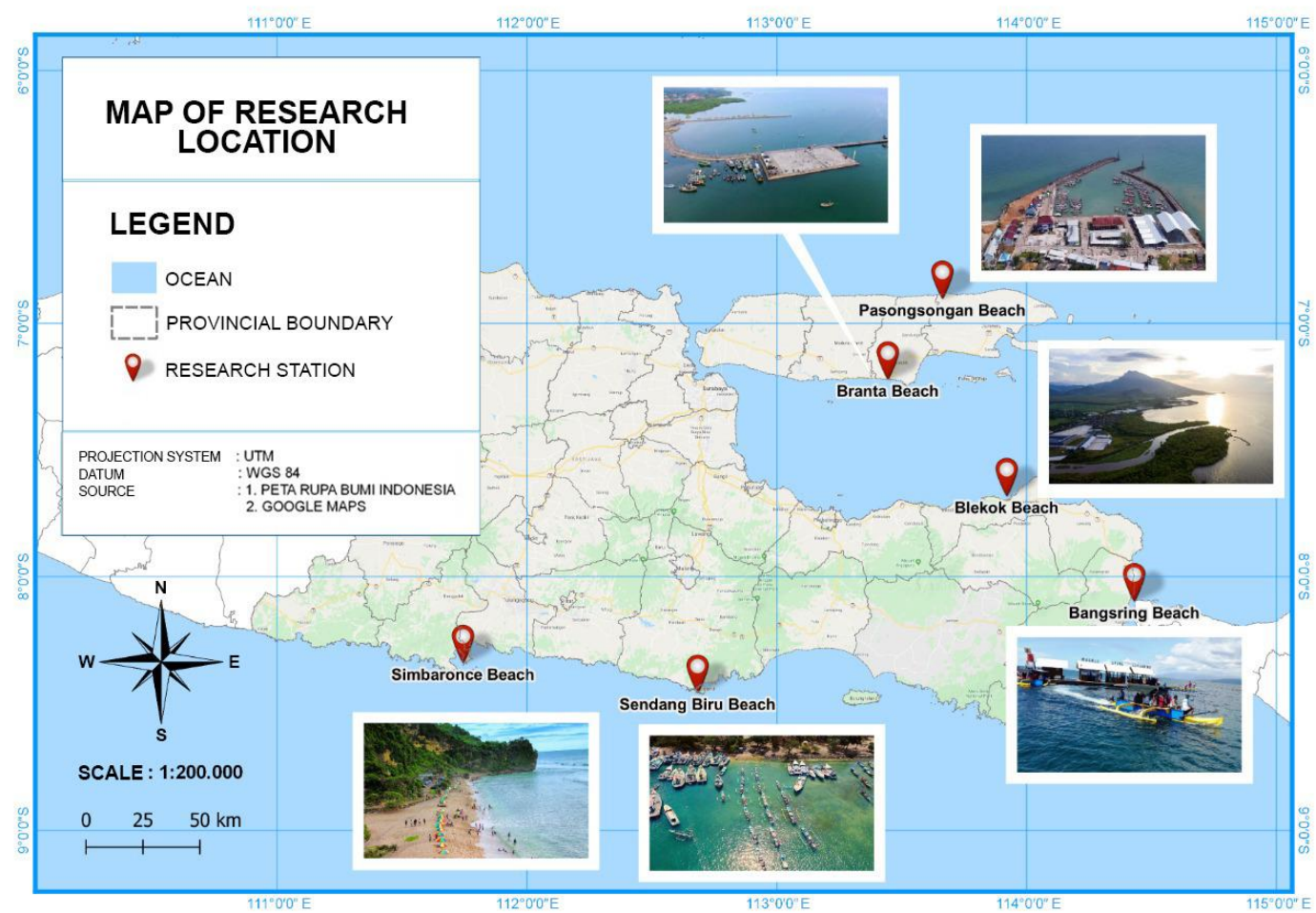

Figure 1. Map of the six research locations of East Java coastal area that represenated by 6 different coastal city areas i.e. Pasongsongan Beach in Sumenep (SUM), Branta Beach in Pamekasan (PAM), Blekok Beach in Situbondo (ST), Bangsring Beach in Banyuwangi (BW), Sendang Biru Beach in South of Malang (SB), and Simbaronce Beach in Trenggalek (TG) 


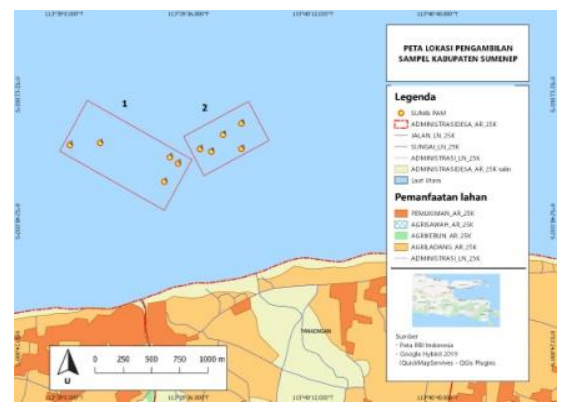

A

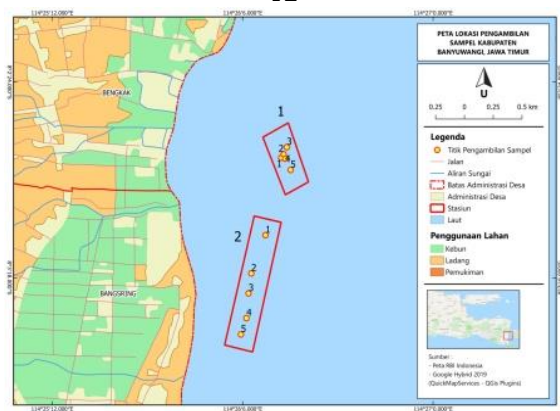

D

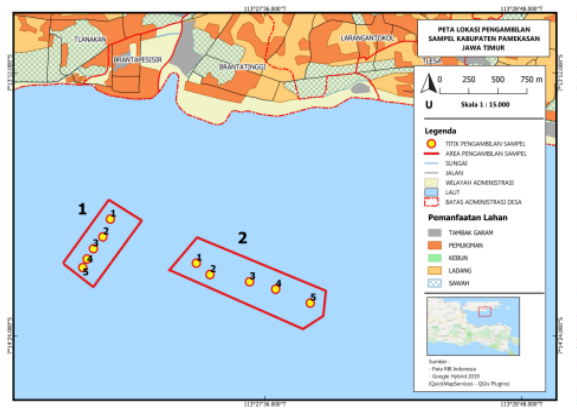

B

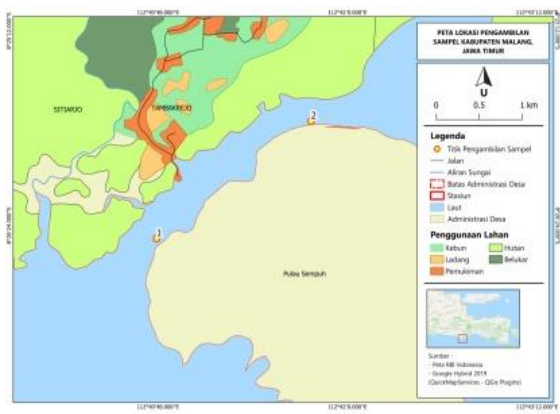

$\mathbf{E}$

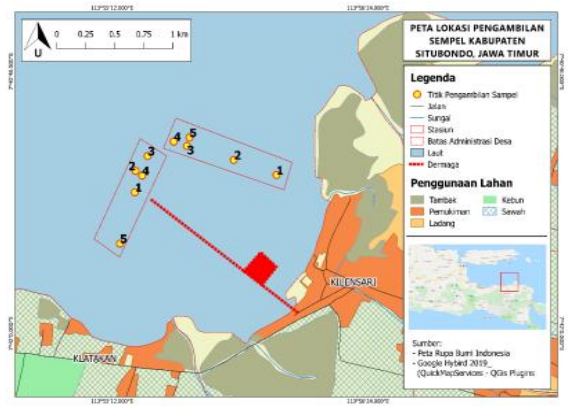

C

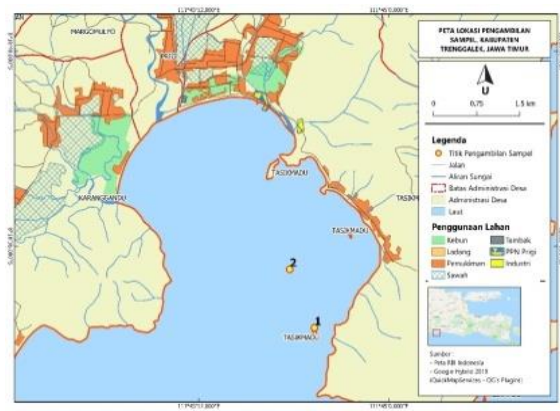

$\mathbf{F}$

Figure 2 to 7. Map of two sampling stations in each of six research sites in East Java, Indonesia coastal area: A. Sumenep (Pasongsongan Beach), B. Pamekasan (Branta Beach), C. Situbondo (Blekok Beach), D. Banyuwangi (Bangsring Beach), E. South of Malang (Sendang Biru Beach), and F. Trenggalek (Simbaronce Beach)

\section{Microalgae analysis}

Microalgae were collected by sieving $100 \mathrm{~L}$ of seawater using plankton nets with specification Wildco 45 um Nitex® mesh (Effendi et al. 2016). These samples were preserved using $1 \mathrm{~mL}$ of Lugol and kept in a cool box while transferred to Laboratorium of Hydrobiology in Faculty of Fisheries and Marine Sciences for identification and analysis using a binocular microscope and identification handbook (Perry 2003; Vuuren et al. 2006).

\section{Microalgae density}

The microalgae abundance were calculated based on Lackey drop micro transect counting (APHA 2005) using formula:

$$
N={ }_{0 p}^{30 i} \times \frac{V r}{3 V o} \times \frac{1}{V s} \times \frac{n}{3 p}
$$

\section{Where:}

$\mathrm{N}$ : Plankton abundance (ind/l)

Oi : Area of cover glass $\left(324 \mathrm{~mm}^{2}\right)$

Op : Area of field of view $\left(1,11279 \mathrm{~mm}^{2}\right)$

$\mathrm{Vr}$ : Sample bottle volume $(250 \mathrm{~mL})$

Vo : Volume drop pipettes $(0,05 \mathrm{~mL})$

Vs : Sieved water Volume by Plankton Net (100 l)

$\mathrm{n} \quad$ : Numbers of Plankton counted

$\mathrm{p} \quad$ : Amount of field of view (50)

\section{Data analysis}

Data on water quality was put on and analyzed using Excel spreadsheet. Species richness was calculated from the total number of species found in a certain population. On the other hand, dominance indices were calculated using the following formula (Odum 1971):

$$
\mathrm{C}=\sum_{i=1}^{s} P i^{2}
$$

Where:

$$
\begin{array}{ll}
\mathrm{C} & \text { : Dominance index } \\
\mathrm{Pi} & : \text { Proportion of individual } \\
\mathrm{i} & : 1,2,3 \ldots \mathrm{s}
\end{array}
$$

Biodiversity index was estimated using ShannonWeaver assuming randomly sampled individual species from a large population (APHA 2005) using formula as follow:

$$
\begin{aligned}
& \mathrm{H}^{\prime}=-\Sigma \mathrm{Pi} \ln \mathrm{Pi} \\
& \mathrm{n}=1
\end{aligned}
$$

Where:

$\mathrm{H}^{\prime}=$ Shannon-Weaver diversity index

$\mathrm{S}=$ total species

$\mathrm{Pi}=$ Relative abundance of each species $(\mathrm{ni} / \mathrm{N})$

According to Prawiradilaga et al. (2003), the criteria for this diversity index are:

$\mathrm{H}^{\prime} \leq 1$ considered low;

$1<\overline{\mathrm{H}}{ }^{\prime} \leq 3$ is in the middle,

$\mathrm{H}^{\prime} \geq 3$ is high 
In order to determine the dispersion of each species in the aquatic environment, the distribution pattern can be observed using the Morisita Index (Id) with the following formula :

$$
\mathrm{Id}=n \frac{\left(\sum x_{i}^{2}-\sum x_{i}\right)}{\left(\sum x_{i}\right)^{2}-\sum x_{i}}
$$

\section{Where:}

n : total sample size

$\mathrm{Xi}$ : number of species

The value of the Morisita index is between -1 to +1 which can be described as the closer the value to +1 the distribution tends to be clumping.

\section{RESULTS AND DISCUSSION}

\section{Water quality measurements}

Based on the result of the water quality measurement (Figure 8 and 9), most of these six areas shown similar values, however in terms of salinity, south coastal areas represented by South of Malang and Trenggalek had relatively lower salinity compare to the north of East Java coastal area. These conditions most probably were due to the station located on the south coast, which is in Sempu Island strait, that it is more affected by the runoff from the mainland compared to the station in north coast of East Java, which is located in more open sea. Concentration of nitrates and phosphates were relatively low in all locations except in Sumenep and South Malang coastal areas, which gave consequences more genera were found in these

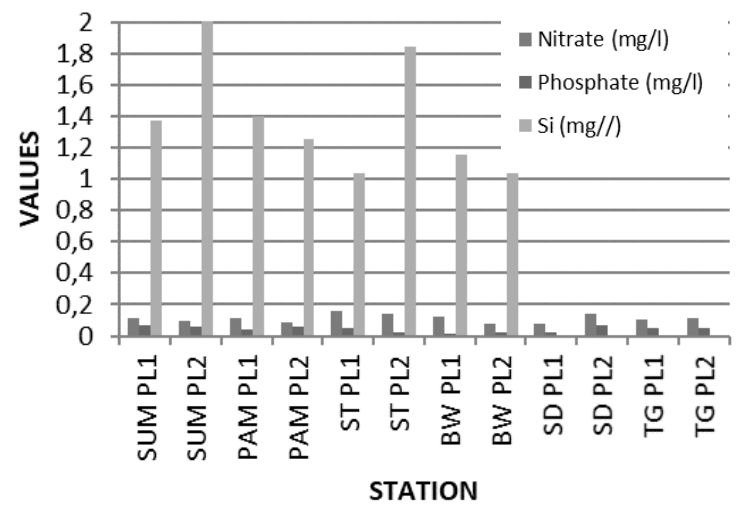

Figure 8. Water Quality parameter (Phosphates, Nitrates, and Si) in Sumenep (Pasongsongan Beach) with station 1 (SUM PL1) and station 2 (SU PL2), Pamekasan ( Branta Beach) with station 1 (PAM PL1) and station 2 (PAM PL2), Situbondo (Blekok Beach) with station 1 (ST PL1) and station 2 (ST PL2), Banyuwangi (Bangsring Beach) with station 1 (BW PL1) and station 2 (BW PL2), South of Malang (Sendang Biru Beach) with station 1 (SD PL 1) and station 2 (SD PL 2), and Trenggalek (Simbaronce Beach) with station 1 (TG PL1) and station 2 (TG PL2) locations. Nutrients have a close relationship with microalgae abundance, especially nitrates and phosphates. The increase in microalgae abundance is generally directly proportional to the increase in nutrients. However, if the nutrient is too high it can cause the unbalanced composition of the microalgae and bloom of one species of microalgae.

\section{Composition and distribution of microalgae}

Based on the microalgae analysis from the six research locations in East Java coastal areas, 35 genera of microalgae were found and most of these genera were belong to division of Bacyllariophyta (22 genera) while another 13 belonged to Dinoflagellata (10 genera), Chlorophyta (1 genus), Ochrophyta (1 genus ) and Granuloreticulosa (1 genus). However, each sub-region that represented by 6 cities around the East Java Province, which were, Sumenep (Pasongsongan Beach), Pamekasan ( Branta Beach), Situbondo (Blekok Beach), Banyuwangi (Bangsring Beach), Trenggalek (Prigi Beach), South of Malang (Sendang Biru Beach) showed different composition of genus and abundance of microalgae at the study location. the Bacyllariophyta group has the highest number of composition and abundance of microalgae as presented in (Table 1) below. Among these 35 genera found in this research, $70 \%$ were found in all locations, another $30 \%$ existed in different locations. This means the composition and distribution of all microalgae found had $70 \%$ similarity in all six locations around the East Java coastal areas. Furthermore, the differences among locations were only $30 \%$. Most of genus that exists in all of locations were mostly belong to Bacyllariophyta division.

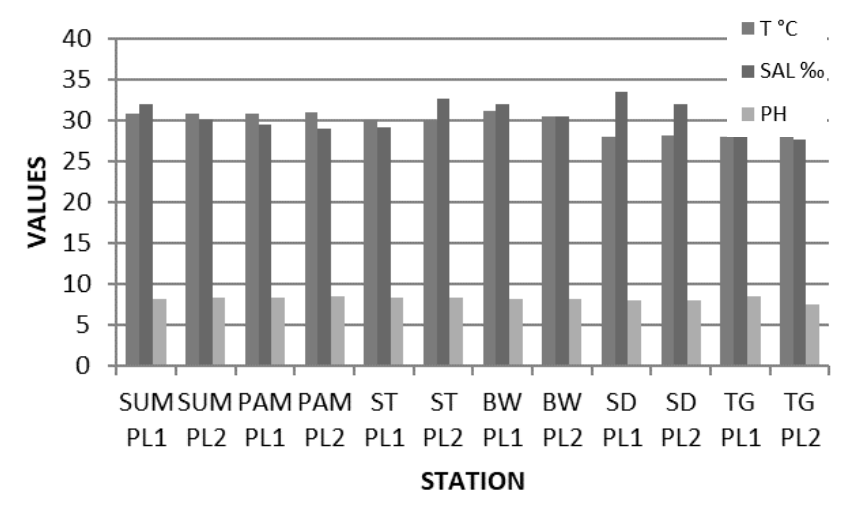

Figure 9. Water Quality parameter (Phosphates, Nitrates, and $\mathrm{pH}$ ) in Sumenep (Pasongsongan Beach) with station 1 (SUM PL1) and station 2 (SUM PL2), Pamekasan ( Branta Beach) with station 1 (PAM PL1) and station 2 (PAM PL2), Situbondo (Blekok Beach) with station 1 (ST PL1) and station 2 (ST PL2), Banyuwangi (Bangsring Beach) with station 1 (BW PL1) and station 2 (BW PL2), South of Malang (Sendang Biru Beach) with station 1 (SD PL1) and station 2 (SD PL 2), and Trenggalek (Simbaronce Beach) with station 1 (TG PL1) and station 2 (TG PL2) 


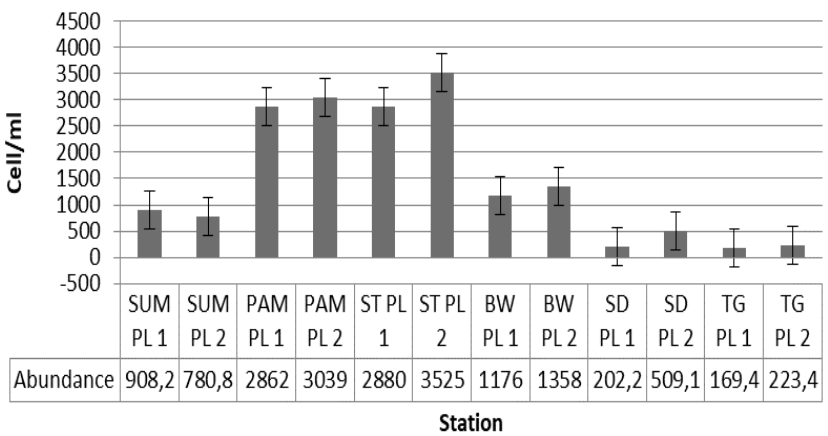

Figure 10. Abundance of microalgae found in sampling location stations: (SUM PL1), (SU PL2), (PAM PL1) and (PAM PL2) representing Madura coast; (ST PL1), (ST PL2), (BW PL1) and (BW PL2) representing Java north coast; (SD PL 1), (SD PL 2), (TG PL1) and (TG PL2) representing Java south coast

Figure 10 shows that Branta Beach of Pamekasan (PAM PL1 and PAM PL2) possessed more microalgae abundance and composition compare to Pasongsongan Beach of Sumenep (SUM PL1 and SUM PL2). The reason might be due to Pamekasan stations are facing Madura strait, while Sumenep stations are facing Java sea. Madura strait is commonly influenced by nutrient upload from east region of Java Island, while the other around Java sea is an open sea. Furthermore, microalgae abundance in Blekok Beach of Situbondo, especially ST PL2, was higher compared to others in Sumenep, Banyuwangi, South Malang and Trenggalek coastal area. This is due to in Blekok Beach, Situbondo regency, there are many fishery activities as well as the existing mangrove ecosystem in the surrounding area, which believed to have high impact on the surrounding areas compared to Bangsring Beach in Banyuwangi, which is relatively close to open Java sea. Microalgae abundance in both stations at Sendang Biru of South Malang and Simbaronce Beach of Trenggalek which are facing the Indian Ocean had relatively similar low values. The lowest abundance value of microalgae was found at Simbaronce Beach, Trenggalek station 1 (TG PL1) with 98 cell $/ \mathrm{mL}$, while the highest was at Blekok Beach Situbondo station 2 (ST PL2) with 324114 cell/mL. Microalgae abundance higher than $20 \times 10^{4}$ cell $/ \mathrm{mL}$ is commonly considered as a bloom. The differences in the microalgae abundance are most probably due to different nutrient upload, fishery activities and existing mangrove ecosystems in the area.

\section{Relative density of microalgae}

The result of microalgae density estimation of the six different research locations in East Java coastal areas that were represented by Sumenep (Pasongsongan Beach), Pamekasan ( Branta Beach), Situbondo (Blekok Beach), Banyuwangi (Bangsring Beach), Trenggalek (Simbaronce Beach), South of Malang (Sendang Biru Beach), showed that different area has different composition, as shown below (Table 2). Different stations in the same area proved to have different biodiversity. The differences that exist in every station presumably due to different land use surrounding the station as well as the nutrient that exist in the water such as nitrate (Setiapermana 2006). The differences in nitrate concentration in waters may cause differences in phytoplankton abundance. In addition, increase and growth of phytoplankton population in waters are related to nutrient availability and light (Meiriyani et al. 2011).

\section{Biodiversity indices}

Estimation of the diversity indices found in these six research locations around the East Java Province showed that several locations, such as surrounding Madura Island and south coastal areas of Java Island possessed relatively higher values compared to others. These index values can be seen in Figure 11 below. The values of microalgae diversity index from all research locations were the opposite of the dominance values in general. When the dominance indices of the microalgae were relatively low, the diversity would be high. Locations with higher value of dominance (Figure 12) have corresponding lower diversity. This fact of dominance most probable will lead to or indicate increasing eutrophication.

\section{Microalgae dominancy}

Coastal area commonly was dominated by microalgae from division Bacillariophyta and Dynophyta, which well known as diatom, as well as Chlorophyta that made the aquatic environment become green or reddish. Dominancy of certain microalgae such as Cerratium sp. and Peridinum sp. can indicate that this area experiencing eutrophication.

The domination index values are showing the level of domination of the genus found from the analysis. As shown in Figure 12 the values are between 0 and 3, meaning that the increasing values indicate domination of certain genus exists and this condition can be used as an early indicator of blooming of the microalgae. However, the microalgae blooming will only occur in the aquatic environment when heavy eutrophication exists. Although domination index for all the research locations was not exceeded the value of 1 which means that there was no domination in all research locations, however, Situbondo and Banyuwangi stations had higher values compared to other locations, indicating domination of some genus had started.

The Morisita indices from all locations presented in Figure 13, shows all are positive, indicating clumped dispersion of microalgae. The highest value was in Bangsring Beach, Banyuwangi coastal area and Blekok Beach at Situbondo coastal area, both representing Java north coast, while the lowest was found in Pasongsongan Beach, in Sumenep, Madura coast. The reason for higher value was due to the Java north coast is situated inside a bay (channel) between East Java and West Bali, which made the phytoplankton relatively clumped. In the opposite was phytoplankton/microalgae that were found in Pasongsongan Beach, Sumenep, northern part of Madura Island, that facing open Jawa Sea, showed that the distribution was relatively dispersed. 
Table 1. Abundance of Microalgae found in East Java, Indonesia coastal areas, i.e. Sumenep (Pasongsongan Beach) with station 1 (SUM PL1) and station 2 (SU PL2), Pamekasan ( Branta Beach) with station 1 (PAM PL1) and station 2 (PAM PL2), Situbondo (Blekok Beach) with station 1 (ST PL1) and station 2 (ST PL2), Banyuwangi (Bangsring Beach) with station 1 (BW PL1) and station 2 (BW PL2), South of Malang (Sendang Biru Beach) with station 1 (PL SD 1) and station 2 (PL SD 2), and Trenggalek (Simbaronce Beach) with station 1 (TG PL1) and station 2 (TG PL2)

\begin{tabular}{|c|c|c|c|c|c|c|c|c|c|c|c|c|c|}
\hline \multirow{2}{*}{ Division } & \multirow{2}{*}{ Genus } & \multicolumn{12}{|c|}{ Microalgae abundance (Cell/mL) } \\
\hline & & SUM PL 1 & SUM PL 2 & PAM PL 1 & PAM PL 2 & TG PL1 & TG PL2 & SD PL1 & SD PL2 & STPL1 & ST PL2 & BW PL1 & BW PL2 \\
\hline \multirow[t]{35}{*}{ Bacillariophyta } & Achnanthes & & & & & & & & & 1273.89 & & & \\
\hline & Asterionella & & & 160.51 & 121.02 & 12738.85 & 1273.89 & & & & & & \\
\hline & Amphiprora & & & & & 2547.77 & & 2547.77 & 8917.20 & & & & \\
\hline & Amphora & & & & & 2547.77 & 10191.08 & 2547.77 & 1273.89 & 3821.66 & 3821.66 & 1273.89 & \\
\hline & Bacteriastrum & 19.11 & 47.13 & 133.76 & 127.39 & & 3821.66 & & & 12738.85 & 14012.74 & 75159.24 & 219108.28 \\
\hline & Biddulphia & 3.82 & 10.19 & 1.27 & & 16560.51 & 11464.97 & 1273.89 & & & & & \\
\hline & Cerataulina & & & 131.21 & 109.55 & & & & & & & & \\
\hline & Climacodium & & & & & & 1273.89 & & & & & & \\
\hline & Climacosphenia & & & & & & 2547.77 & & 1273.89 & & & & \\
\hline & Chaetoceros & 121.02 & 147.77 & 1342.68 & 1661.15 & 76433.12 & 256050.96 & 100636.94 & 38216.56 & 640764.33 & 694267.52 & 1491719.75 & 1634394.90 \\
\hline & Coscinodiscus & 15.29 & 15.29 & 5.10 & 7.64 & 8917.20 & 7643.31 & 3821.66 & 2547.77 & 5095.54 & 10191.08 & 3821.66 & \\
\hline & Cyclotella & 11.46 & 6.37 & 2.55 & 1.27 & 14012.74 & . 17834.39 & 5095.54 & & 7643.31 & 3821.66 & 2547.77 & \\
\hline & Cymbella & & & & & 7643.31 & 10191.08 & 7643.31 & 12738.85 & 3821.66 & & 2547.77 & \\
\hline & Dictyiosolen & & 7.64 & 3.82 & 1.27 & & & & & 8917.20 & 8917.20 & 25477.71 & 26751.59 \\
\hline & Diploneis & & & & & & 6369.43 & & & & & & \\
\hline & Ditylum & & 3.82 & 7.64 & 3.82 & & & & & & & & \\
\hline & Gyrosigma & & & & & & 3821.66 & & & 5095.54 & & & \\
\hline & Licmophora & & & & & 3821.66 & 3821.66 & & & & & & \\
\hline & Hemialus & 14.01 & 26.75 & 2.55 & & & & & & & & 2547.77 & \\
\hline & Hyalodiscus & 3.82 & 2.55 & & & & & & & & & & \\
\hline & Leptocylindrus & - & 5.10 & 30.57 & 6.37 & - & - & - & - & - & - & 7643.31 & 6369.43 \\
\hline & Lithodesmium & - & - & - & - & - & - & - & - & - & - & 2547.77 & 1273.89 \\
\hline & Melosira & 15.29 & 2.55 & - & - & - & - & - & - & - & - & - & - \\
\hline & Navicula & 2.55 & 10.19 & 5.10 & 1.27 & 35668.79 & 72611.46 & 10191.08 & 5095.54 & 10191.08 & 7643.31 & 1273.89 & 1273.89 \\
\hline & Nitzschia & 12.74 & 8.92 & 155.41 & 146.50 & 76433.12 & 179617.83 & 53503.18 & 24203.82 & 266242.04 & . 363057.32 & 56050.96 & 43312.10 \\
\hline & Pleurosigma & 1.27 & 2.55 & - & 1.27 & 5095.54 & 7643.31 & 1273.89 & - & 5095.54 & 3821.66 & - & 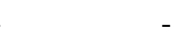 \\
\hline & Pinnularia & 1.27 & 1.27 & - & - & 11464.97 & 24203.82 & 2547.77 & 6369.43 & 6369.43 & 6369.43 & - & . \\
\hline & Rhabdonema & - & - & - & - & 3821.66 & 2547.77 & 1.27 & - & - & - & - & - \\
\hline & Rhizosolenia & 12.74 & 20.38 & 429.30 & 629.30 & 7643.31 & 28025.48 & 6369.43 & 7643.31 & 11464.97 & 7643.31 & 10191.08 & 12738.85 \\
\hline & Striatella & - & - & - & - & - & 1273.89 & - & - & - & - & - & - \\
\hline & Surirella & - & - & - & - & 8917.20 & 1273.89 & - & - & - & 1273.89 & - & - \\
\hline & Skeletonema & - & - & - & - & - & - & - & - & 3272611.46 & 4081528.66 & 26751.59 & 12738.85 \\
\hline & Synedra & 2.55 & & 243.31 & 76.43 & - & 7643.31 & - & 1273.89 & - & 1273.89 & 2547.77 & \\
\hline & Thalassionema & 25.48 & 136.31 & 84.08 & 71.34 & - & 7643.31 & - & - & 43312.10 & 26751.59 & 5095.54 & 14012.74 \\
\hline & Triceratium & - & - & - & - & - & - & - & - & - & 1273.89 & - & . \\
\hline
\end{tabular}




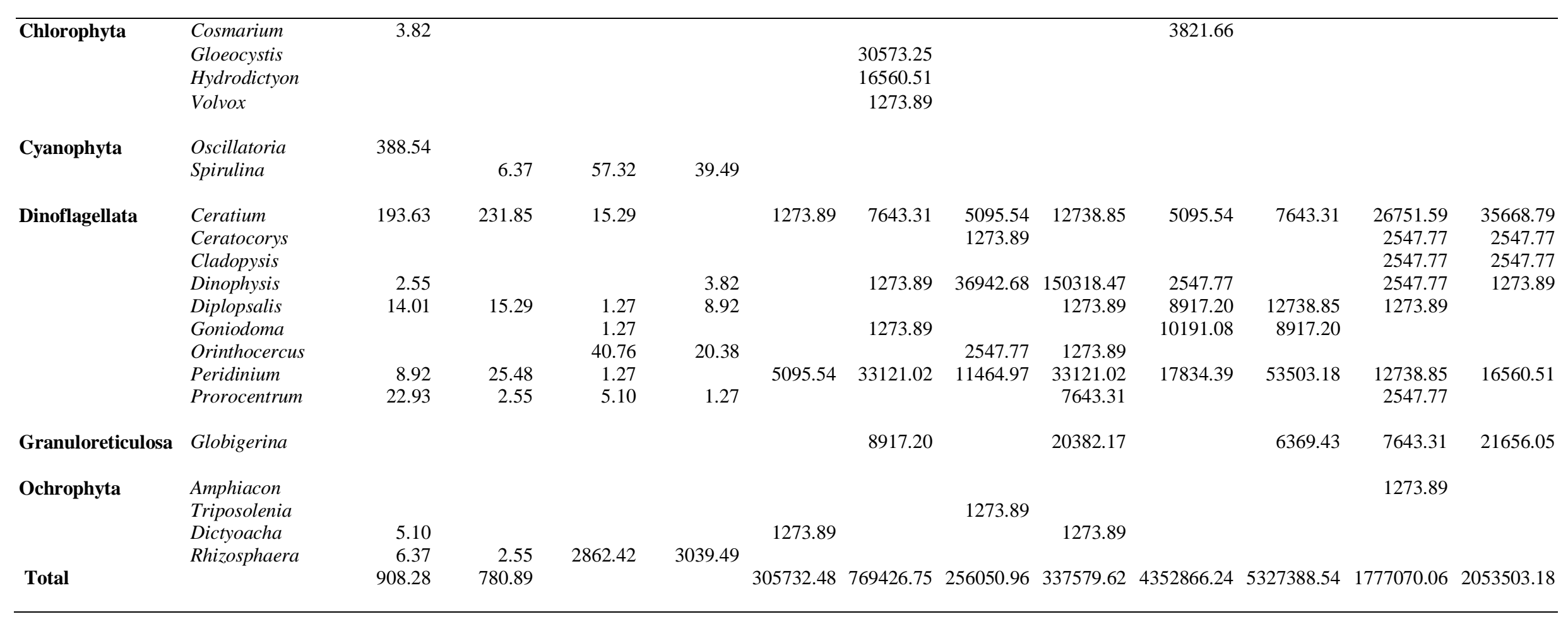


Table 2. Relative Density of Microalgae found in sampling location station 1 (SUM PL1) and station 2 (SUM PL2), station 1 (PAM PL1) and station 2 (PAM PL2), station 1 (ST PL1) and station 2 (ST PL2), station 1 (BW PL1) and staion 2 (BW PL2), station 1 (PL SD 1) and station 2 (PL SD 2), and station 1 (TG PL1) and station 2 (TG PL2).

\begin{tabular}{|c|c|c|c|c|c|c|c|c|c|c|c|c|c|}
\hline \multirow{2}{*}{ Divisi } & \multirow{2}{*}{ Genus } & \multicolumn{12}{|c|}{ Relative Density (\%) } \\
\hline & & SUM PL 1 & SUM PL 2 & PAM PL 1 & PAM PL 2 & TGPL1 & TGPL2 & SDPL1 & SDPL2 & STPL1 & STPL2 & BWPL1 & BWPL2 \\
\hline \multirow[t]{36}{*}{ Bacillariophyta } & Achnanthes & & & & & & & & & 0.40 & & & \\
\hline & Asterionella & & & 5.607477 & 3.98 & & 3.80 & 4.20 & 0.20 & 4.10 & 0.20 & & \\
\hline & Amphiprora & & & & & 1.00 & 2.60 & 0.80 & & 0.80 & & 1.00 & 2.60 \\
\hline & Amphora & & & & & 1.00 & 11.30 & 0.80 & 1.30 & 0.80 & 1.30 & 1.00 & 0.40 \\
\hline & Bacteriastrum & 2.10 & 6.04 & 4.67 & 4.19 & & & & 0.50 & & 0.50 & & \\
\hline & Biddulphia & 0.420757 & 1.305057 & 0.044504 & & 0.50 & & 5.40 & 1.00 & 5.40 & 1.50 & 0.50 & \\
\hline & Cerataulina & & & & 3.60 & & & & & & & & \\
\hline & Climacodium & & & & & & & & 0.20 & & 0.20 & & \\
\hline & Climacosphenia & & & & & & 0.40 & & 0.30 & & 0.30 & & 0.40 \\
\hline & Chaetoceros & 13.32398 & 18.92333 & 46.90699 & 54.65 & 38.20 & 0.40 & 25.00 & 33.60 & 24.90 & 33.20 & 38.20 & 11.20 \\
\hline & Coscinodiscus & 1.683029 & 1.957586 & 0.178015 & 0.25 & 1.40 & 3.80 & 2.90 & 1.00 & 2.90 & 1.00 & 1.50 & 0.70 \\
\hline & Cyclotella & 1.262272 & 0.815661 & 0.089008 & 0.04 & 1.90 & & 4.60 & 2.30 & 4.60 & 2.30 & 1.90 & \\
\hline & Cymbella & & & & & 2.90 & 44.50 & 2.50 & 1.30 & 2.50 & 1.30 & 2.90 & 3.70 \\
\hline & Dictyiosolen & & & & 0.04 & & & & & & & & \\
\hline & Diploneis & & & & & & & & 0.80 & & 4.00 & & \\
\hline & Ditylum & & 0.49 & 0.267023 & 0.13 & & & & & & & & \\
\hline & Gyrosigma & & & & & & & & 0.50 & & 0.50 & & \\
\hline & Licmophora & & & & & & & 1.30 & 0.50 & 1.20 & 23.30 & & \\
\hline & Hemialus & 1.542777 & 3.425775 & 0.089008 & & & & & & & & & \\
\hline & Hyalodiscus & 0.420757 & 0.326264 & & & & & & & & & & \\
\hline & Leptocylindrus & & 0.65 & & 0.21 & & & & & & & & \\
\hline & Lithodesmium & & & & & & & & & & & 1.00 & 0.40 \\
\hline & Melosira & 1.683029 & 0.326264 & & & & & & & & & & \\
\hline & Navicula & 0.280505 & 1.305057 & 0.178015 & 0.04 & 3.90 & 0.40 & 11.70 & 9.50 & 11.60 & 4.30 & 3.90 & 1.50 \\
\hline & Nitzschia & 1.402525 & 1.141925 & 5.429462 & 4.82 & 20.30 & 9.80 & 25.00 & 23.60 & 24.90 & 3.10 & 20.40 & 7.10 \\
\hline & Pleurosigma & 0.140252 & 0.326264 & & 0.04 & 0.50 & & 1.70 & 1.00 & 1.70 & 3.60 & 0.50 & \\
\hline & Pinnularia & 0.140252 & 0.163132 & & & 1.00 & & 3.80 & 3.20 & 3.70 & 0.30 & 1.00 & 1.90 \\
\hline & Rhabdonema & & & & & & & 1.30 & 0.30 & 1.20 & 0.20 & & \\
\hline & Rhizosolenia & 0.014025 & 2.610114 & 0.044504 & & & & 2.50 & 3.70 & 2.50 & 0.20 & & \\
\hline & Striatella & & & & & & & & 0.20 & & 1.00 & & \\
\hline & Surirella & & & & & & & & & 2.90 & 1.00 & & \\
\hline & Skeletonema & & & & 20.70 & & & & 0.20 & & & & \\
\hline & Synedra & 0.280505 & & & & & & & 1.00 & & & & \\
\hline & Thalassionema & 2.805049 & 17.45514 & 8.500223 & 2.51 & & & & & & & & \\
\hline & Triceratium & & & & & & & & & & & & \\
\hline & Thalassiothrix & & 5.38 & & 2.35 & & & & & & & & \\
\hline
\end{tabular}




\begin{tabular}{|c|c|c|c|c|c|c|c|c|c|c|c|c|c|}
\hline Chlorophyta & $\begin{array}{l}\text { Cosmarium } \\
\text { Gloeocystis } \\
\text { Hydrodictyon } \\
\text { Volvox }\end{array}$ & 0.420757 & & & & & & & 2.20 & 2.20 & $\begin{array}{l}0.50 \\
9.40\end{array}$ & & \\
\hline Cyanophyta & $\begin{array}{l}\text { Oscillatoria } \\
\text { Spirulina }\end{array}$ & 42.777 & 0.82 & & & & & & & & & & \\
\hline Dinoflagellata & $\begin{array}{l}\text { Ceratium } \\
\text { Ceratocorys } \\
\text { Cladopysis }\end{array}$ & 21.31837 & 29.69005 & 2.00267 & 1.30 & $\begin{array}{l}1.90 \\
0.50\end{array}$ & 0.40 & 0.40 & 1.00 & 0.40 & 1.00 & $\begin{array}{l}1.90 \\
0.50 \\
1.00\end{array}$ & $\begin{array}{l}3.70 \\
0.70\end{array}$ \\
\hline & $\begin{array}{l}\text { Dinophysis } \\
\text { Diplopsalis }\end{array}$ & $\begin{array}{l}0.280505 \\
1.542777\end{array}$ & 1.957586 & 0.534045 & 0.13 & 14.00 & $\begin{array}{l}6.00 \\
1.50\end{array}$ & & $\begin{array}{l}0.20 \\
0.80\end{array}$ & & 1.20 & 14.10 & $\begin{array}{r}44.20 \\
0.40\end{array}$ \\
\hline & $\begin{array}{l}\text { Goniodoma } \\
\text { Orinthocercus } \\
\text { Peridinium } \\
\text { Prorocentrum }\end{array}$ & $\begin{array}{l}0.981767 \\
2.524544\end{array}$ & $\begin{array}{l}3.262643 \\
0.326264\end{array}$ & $\begin{array}{l}0.044504 \\
1.424121 \\
0.044504\end{array}$ & $\begin{array}{l}0.29 \\
0.67\end{array}$ & $\begin{array}{l}1.00 \\
4.30\end{array}$ & 1.90 & 1.70 & $\begin{array}{l}0.20 \\
4.30\end{array}$ & 1.70 & $\begin{array}{l}2.10 \\
1.00\end{array}$ & $\begin{array}{l}1.00 \\
4.40\end{array}$ & $\begin{array}{l}0.40 \\
9.70\end{array}$ \\
\hline Granuloreticulosa & Globigerina & & & & & & 7.20 & & 1.20 & & 0.20 & & 6.00 \\
\hline Ochrophyta & $\begin{array}{l}\text { Amphiacon } \\
\text { Triposolenia } \\
\text { Dictyoacha } \\
\text { Rhizosphaera }\end{array}$ & $\begin{array}{r}0.56101 \\
0.701262\end{array}$ & 0.978793 & & & & 0.40 & 0.40 & & 0.40 & 0.80 & 0.50 & 0.40 \\
\hline
\end{tabular}




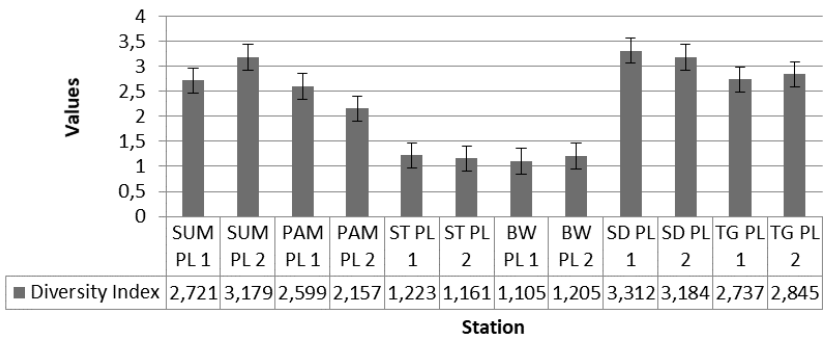

Figure 11. Diversity indices of microalgae found in sampling locations stations: (SUM PL1), (SU PL2), (PAM PL1) and (PAM PL2) representing Madura coast; (ST PL1), (ST PL2), (BW PL1) and (BW PL2) representing Java north coast; (SD PL 1), (SD PL 2), (TG PL1) and (TG PL2) representing Java south coast

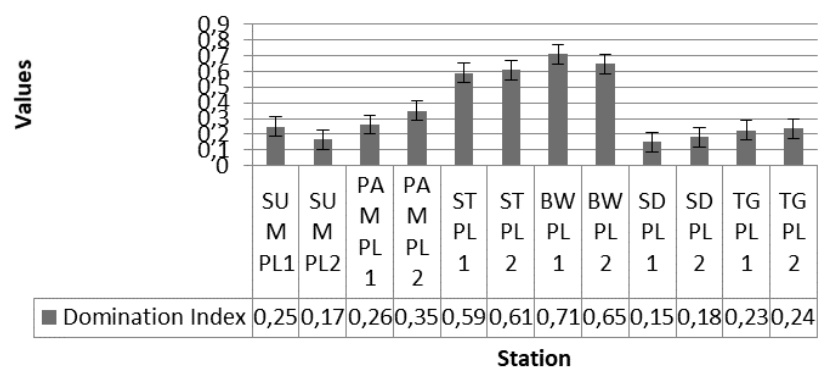

Figure 12. Dominance indices of microalgae found in al sampling locations: (SUM PL1), (SU PL2), (PAM PL1) and (PAM PL2) representing Madura coast; (ST PL1), (ST PL2), (BW PL1) and (BW PL2) representing Java north coast; (SD PL 1), (SD PL 2), (TG PL1) and (TG PL2) representing Java south coast

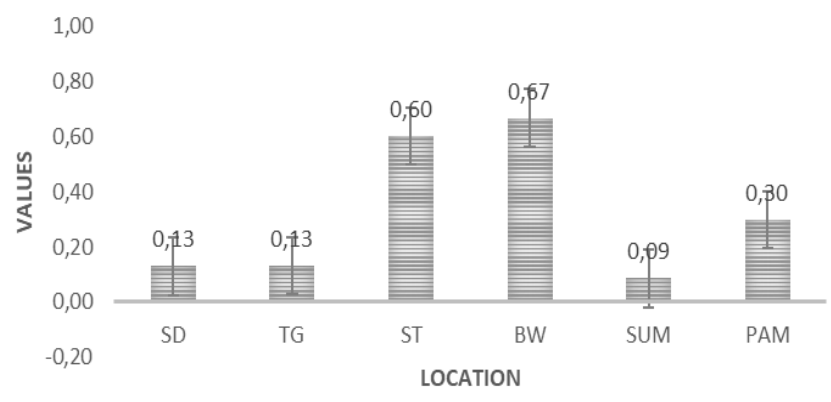

Figure 13. Morisita Index of six different sampling location around east java and Madura coastal areas. SD: Sendang Biru Beach, South of Malang Coastal Areas;TG: Prigi Beach at Trenggalek Coastal Area; ST: Blekok beach Situbondo Coastal Area; BW: Bangsring Beach, Banyuwangi Coastal Area; SUM: Pasongsongan Beach, in Sumenep Coastal Area; PAM: Branta.Beach at Pamekasan Coastal Area

Contrary to the relatively high anthropogenic development in all study sites, water quality parameters in all locations generally have good similar $\mathrm{pH}$ values. Nitrate and phosphate values in Sumenep and Malang coastal area is relatively higher than other locations, which are related to the high microalgae abundance in those areas. Biodiversity of microalgae found in East Java coastal areas that is represented by genus composition in six different cities, i.e. Sumenep (Pasongsongan Beach), Pamekasan ( Branta Beach), Situbondo (Blekok Beach), Banyuwangi (Bangsring Beach), South of Malang (Sendang Biru Beach), and Trenggalek (Simbaronce Beach) has similarity around $70 \%$ and only $30 \%$ differences among locations, indicating high similarity of microalgae population in East Java coastal area. Identifications result showed that among 35 genera that were found, most of the Genus were belong to Bacyllariophyta division. There was no domination found in each location observed, indicating high microalgae diversity is present in the aquatic environments, which are still in optimum condition as confirmed by results of water quality parameter analysis.

\section{ACKNOWLEDGEMENTS}

This research funds came from the RKI-IPB Program under the Kemenristek-DIKTI 2019 of Indonesia. The authors wish to express gratitude to all parties who had given permits and assisted in the field and laboratory works.

\section{REFERENCES}

Alaswad A, Dassisti M, Prescott T, Olabi AG. 2015. Technologies and developments of third-generation biofuel production. Renew Sustain Energ Rev 51: 1446-1460.

Ali N, Ting Z, Khan YH, Athar MA, Ahmad V, Idress M. 2014. Making biofuels from microalgae-A review of technologies. J Food Sci Technol 1 (2): 7-14.

Amini S and Susilowati R.2010. Biodiesel Production from Microalgae Botryococcus braunii. Squalen5 (1): 23-32.

APHA [American Public Health Association]. 1989. Standard Methods for The Examination of Water and Wastewater. American Public Control Federation. 20th ed., American Public Health Association, Washington DC.

APHA [American Public Health Association]. 2005. Standard Method for The Examination of Water and Wastewater. 21th ed. American Public Health Association Inc., New York.

Bengen DG. 2000. Sampling Techniques and Analysis for Biophysical Data of Coastal Resources. PKSPL IPB, Bogor. [Indonesian]

Chisti Y. 2007. Biodiesel from microalgae. J Biotechnol Adv 25: 294-306.

Davis CC. 1955. The Marine and Fresh Water Plankton. Michigan State University Press, USA.

Dong T, Knoshaug EP, Davis Ryan, Lieve ML, Laurens, Wychen SV, Pienkos PT, Nagle N. 2016. Combined algal processing: A novel integrated biorefinery process to produce algal biofuels and bioproducts. Algal Res 19: 316-323

Effendi H, Kawaroe M, Lestaria DF, Mursalina, Permadia T. 2016. Distribution of phytoplankton diversity and abundance in Mahakam Delta, East Kalimantan. Procedia Environ Sci 33: 496-504.

Meiriyani F, Ulqodry TZ, Putri WAK. 2011. Phytoplankton composition and distribution in the estuary of Muara Sungai Way Belau, Bandar Lampung. Maspari J 3: 69-77. [Indonesian]

Odum EP. 1971. Fundamentals of Ecology. WB. Saunders, New York.

Perry, R. 2003. A Guide to the Marine Plankton of Southern California. UCLA Ocean Globe and Malibu High School, Los Angeles, CA.

Ponce-Palafox JT, Arredondo-Figueroa JL, Vernon-Carter EJ. 20016. Carotenoids from plants used in diets for the culture of the Pacific white shrimp (Litopenaeus vannamei), Revista Mexicana. de Ingenieria Chuimica 5 (2): 157-1655.

Prartono T, Kawaroe M, Sari DW, Augustine D. 2010. Fatty acid content of Indonesia Aquatic Microalgae. Hayati J Biosci 17 (4): 196-200.

Prawiradilaga D, Suyanto DMA, Noerdjito WA, Saim A, Purwaningsih, Rachmatika I, Susiarti S, Shidiq I, Marakarmah A, Sinaga MH, 
Chalik E, Ismael, Maharani M, Purwanto Y, Waluyo EB. 2003. Final Report on Biodiversity of Tesso Nilo. Research Center for BiologyLIPI and WWF Indonesia, Jakarta.

Riberio LA, Pereira da Silva P. 2013. Surveying techno-economic indicators of microalgae biofuel technologies. J Renew Sustain Energ Rev 25: 89-96.

Setiapermana D. 2006. Nitrogen cycles in the sea. Oseana 31: 19-31.

Suyono EA. Fahrunnida, Nopitasari S, Utama IV. 2016. Identification of microalgae species and lipid profiling of glagah consortium for biodiesel development from local marine resources. J Eng Appl Sci 11 (16): 1819-6608.

Vuuren SJ van, Taylor J, Gerber A, van Ginkel C. 2006. Easy Identification of the Most Common Freshwater Algae: A Guide for the Identification of Microscopic Algae in South African Freshwaters. North-West University and Department of Water Affairs and Forestry (DWAF), Pretoria, SA. 